DOI: $10.17951 /$ bc.2020.5.123-131

\begin{tabular}{lcr}
\hline & ANNALES \\
& UNIVERSITATIS MARIAE CURIE-SKŁODOWSKA & \\
LUBLIN - POLONIA & \\
VOL.V & SECTIO M & 2020 \\
\hline
\end{tabular}

\author{
Roman Ivashko \\ University of Lviv of Ivan Francs \\ romanivashko1@gmail.com \\ ORCID //orcid.org/0000-0002-7265-464X
}

\title{
The early history of the Roman Catholic parish in Bibrka
}

Bibrka (Bóbrka) is a town that is located in the basin of the Dniester River ${ }^{1}$, and a local historian, Yaropolk Tsaryk, found documents that testify about the presence of the Orthodox monastery in the vicinity of the city being already in existence in the early $13^{\text {th }}$ century ${ }^{2}$. The first written records about the Boberka River belong to 1211 (1214) and $1238^{3}$. Prince Daniel Romanovich held Halych then, but systematic documentation, especially in Latin, on the history of the lands of Halych, only began after Queen of Poland Jadwiga entered Lviv in 1387. Her husband, King Władysław II Jagiełło declared the land of Lviv a personal royal domain next year".

The purpose of the article is to analyze written records concerning the history of the Roman Catholic parish in Bibrka; to make original interpretations of the facts and events of history of the Roman Catholic parish and of interfaith

\footnotetext{
1 Nowadays, Bibrka is located in Peremyshlyany district, Lviv region.

2 Z. Tsaryk, Ya. Tsaryk, Misto z bobrom na herbi [The city with a beaver on the coat], Bibrka-Lviv 2009.

3 The Hypatian Codex is the primary source on the events. It is stored at the National Library of Russia in Saint Petersburg.

${ }^{4}$ Lviv, the Central State Historical Archive in Lviv, fund 131: the Collection of charters on parchment, description 1, case No. 16: Darcha hramota syniv lvivskoho pidkomoriia Vnucheka Petra rektoru kostelu u Bibrtsi Matviiu ta yoho nastupnykam na stavok z hrebleiu u s. Strilky [The gift charter of the sons of the land surveyor of Lviv Peter Wnuchek to the parson of the church in Bibrka Matviy and his successors for the pond with the dam in the village of Strilky]
} 
relations in Bibrka in the early years of the $15^{\text {th }}$ century up to the 60 s of the same century. The last generalization on the topic belongs to Dr. Tomasz Zaucha ${ }^{5}$.

The Soviets believed that the Roman Catholic parish in Bibrka was founded in 1402. The memorial tablet on the North wall of the temple of St. Nicholas and St. Anne in the city bears witness about this:

\author{
Ukrainian Soviet Socialistic Republic \\ Monument of architecture \\ The temple \\ 1402 \\ Guard by the state \\ Damaging will be punished according to law
}

The source of the date is unknown. A contemporary Ukrainian researcher of local history, Orest Matsiuk, considers that the date of the creation of the parish is $1405^{6}$. However, the researcher of the history of property of the Roman Catholic Archdiocese of Lviv, Bp. Marian Buczek, carefully limited the date just to the early $15^{\text {th }}$ century ${ }^{7}$.

The Polish knight, Zawisza Czarny, traditionally is considered as the founder of the Roman Catholic church in Bibrka. According to unverified sources, one of the icons of the temple was even painted on his shield. The Church jurisdiction in the lands of Lviv belonged to the protégé of Queen Jadwiga, Archbishop of Halych, Jacob Strepa, at this time ${ }^{8}$. But the struggle on ecclesiastical jurisdiction in the lands of Rus' was, however, still ongoing between the King of Germany and Hungary, Sigismund Luxemburg, and Grand Duke of Lithuania, Vytautas the Great. The king was looking for revenge on the Ottoman Turks and officially gave away in $1412^{9}$. Having met defeat in battle (near the Vorskla River) against Edigey, the emir of the Golden Horde, Vytautas the Great then ended

5 T. Zaucha, Kościół parafialny p. w. św. Mikołaja w Bóbrce [in:] Materiały do dziejów sztuki sakralnej na ziemiach Wschodnich dawnej Rzeczypospolitej, J. Ostrowski (ed.), cz. 1. t. 11: Kościoły i klasztory Rzymskokatolickiego dawnego województwa Ruskiego, Kraków 2003, pp. 21-36

${ }^{6}$ O. Matsiuk, Zamky ta fortetsi Zakhidnoi Ukrainy [Castles and fortresses of the Western Ukraine], 2-d ed., Lviv 2005, p. 25

7 M. Buchek, I. Sedelnyk, Lvivska arkhidiietseziia latynskoho obriadu. Parafii, kostely ta kaplytsi [The Lviv archidecese of the Latin rite. Parishes, churches and chapels], Lviv 2004, part 1, p. 41

8 W. Abraham, Jakub Strepa arcybiskup halicki: 1391-1409, Kraków 1908.

9 Kraków, Biblioteka Jagiellońska, rkps. 33: Historiae Polonicae, tomus II, pp. 279v - 281r 
his attempts to obtain the jurisdiction ${ }^{10}$. Thus, the possible foundation of the temple in Bibrka was in favour of the Jagiellons. However, the conclusions of Bp. Buczek opened the possibility for an alternative version of the founding of the parish around 1410, when the battle of Grunwald took place. Indeed, by this time German and Polish settlers already freely professed the Roman Catholic faith according to the granting of the Magdeburg law in 1433, by King of Poland Władysław II Jagiełło ${ }^{11}$.

The proper transcription of the donation for the Roman Catholic parish in Bibrka is found in further royal privileges. In particular, King of Poland Sigismund I the Old confirmed on August 7, 1547, the relevant privilege of his predecessor King Casimir IV Jagiellon of May 19, 1469, about the re-provision of the Magdeburg law to the community of Bibrka (Bobrka) ${ }^{12}$. It is possible that this is the second grant of the Magdeburg law, as a separate document was made because the number of Polish or German Catholics in the city had increased compared with 1433. Both kings also confirmed donations to the local Roman Catholic parish:

From the excellent Matthew from Starolomza, the parson of the parish church in Bobrka, and the scribe of the land of Halych, our faithful elect, we learned the narrative, that for protection rights of his church, which were specially described and expressed in the called privilege. Full content of this privilege was joined and requested. Thus, it should not request for other privileges, as cheating written records for the mentioned church. We wish to appoint once again and rewrite these expressed in the privilege of Bobrka, rights in this appointment. Therefore, first, seeing the content of the mentioned privilege, that for this parish church and its parson two plots, and fields, and areas for the house were entered and provided. Regarding tithing, according to this privilege, we approved the quarter of Polish hryvna ${ }^{13}$. Besides, we determine that Missalia, or annual duty, or Meschne from each plot possession through obligated and peasants should be the first sheaf of rye and the second of oats, and also that the carol donation, or columbatio, from whatever board in accordance as in other cities situated in the lands of Rus', the decision to pay through

\footnotetext{
${ }^{10}$ Kraków, Biblioteka Książąt Czartoryskich, 289 Perg.: Aleksander czyli Witold wielki książę litewski przystępuje do zawartego między Władysławem królem polskim i Zygmuntem królem rzymskim i węgierskim układu, którego treść powtarza.

${ }^{11}$ Confirmed by King Sigismund II August in 1552. Warsaw, Archiwum Główny Akt Dawnych, zespół No. 4: MK, seria No. 1, sygnatura No. 82, fol. 89v - 91r

${ }^{12}$ Kings of Poland Casimir IV Jagiellon and Sigismund I the Old also were Grand Dukes of Lithuania.

${ }^{13}$ Fertum or fertonum.
} 
inhabitants of the mentioned city, and adjacent farms to pay whatever effectively follows, as has been in such cases until now ${ }^{14}$.

The first original version of this confirmed document is not known yet. The time of its creation can vary from the beginning to the middle of the $15^{\text {th }}$ century.

The next recently discovered donation in favour of the Roman Catholic parish in Bibrka belonged to the descendants of the land surveyor of Lviv, Peter Wnuchko of Kutna, who had ownership of Bibrka (Bobrka) since $1436^{15}$. The sons of Peter Wnuchko, namely, Nicholas, Peter, Scibor, Andrew and John, gave the dam and the pond to the parson of the Roman Catholic parish of Bibrka Matthew of Lakno ${ }^{16}$ on December 26, 1463. They documented the following:

In the name of God. Amen. For the eternal memory of the thing, and in order not to end through time and not to disappear, it was necessary to official documented testimonies of witnesses to last many years. That is why we Nicholas, Peter, Scibor, Andrew and John, the sons of once a brave warrior, the lord Peter Wnuchek, the heirs of the land surveyor of Lviv, convening ourselves mature, inseparably noticing the church of the Holy Virgin Mary in Bobrka, honourably having endowed it, in great part lacks and is deprived of ponds, as is usual for this in lands of Rus' in all places, where parsons of churches are accustomed to keep ponds. Observing to this short and unsecured life and in the future as well,

${ }^{14}$ Postremo hono//rabilis Mathia de Starolomza, Rectoris Ecclesie parrochialis in Bobrka, // et Notarii terre Haliciensis, fidelis nostri dilecti narratione didicumus, // eum pro tuendis Ecclesie sue Juribus, que in Privilegio advoca//ti ibidem specialiter sunt descripta et expressa. Ipsa Privilegia advoca//tie plerumque contigit quesivisse et mendicasse. Ne igitur ob alieno//rum Privilegiorum mendicationem, memorata Ecclesia in suis introi//tibus frauderetur. Jura eiusdem, que in dicti advocati, ac sue // advocatie in Bobrka Privilegiis sunt expressa, in presentibus desi// gnari, et transsumi specialiter volumus. Imprimis igitur, Pri//vilegium antedictum continere videbatur, quomodo pro ipsa Ecclesia par//rochiali, et eius rectoribus, duo lanei, nec non ortus, et area pro domo // liberi ascribuntur et donantur. Pro decima vero de uno fertone Po//lonicali statuit ipsum Privilegium responderi. Item decernit, quod Mis//salia, seu annone, alias Meschne de quolibet laneo possesso, per ad//vocatum et cmetones, per unum truncum siliginis, et per secundum avene. Nec non datio seu columbatio, de qualibet mensa juxta quod in aliis civitatibus in terra Russie situatis solvi sulita sunt, per incolas predicti opidi, et villarum ad ipsum pertinentium cum efectu quomodolibet exolvantur, salva tamen consuetudine in talibus hactenus // observata. Warsaw, AGAD, zespół No. 4: MK, seria No. 1, sygnatura No. 54, fol. 183r. The Ukrainian and Canadian local historian Taras Shakh found the later confirmation of the privilege by King Sigismund III on April 3, 1597. Besides, subsequent kings could confirm the document. T. Shakh, Bibrka na perekhresti vikiv: chas, podii, liudy [Bibrka at the crossroads of ages: time, events, people], Lviv 2019, pp. 40-47

${ }^{15}$ Zbiór dokumentów małopolskich, wyd. Irena Sułkowska-Kuraś i Stanisław Kuraś, Wrocław 1975, Cz. 8, No. 2191

${ }^{16}$ It seems that it was Lakno. 
preferring salvation and our souls, and to help our parents, our predecessors, who had already ended their lives, we are prepared to place together with the dam within borders and boundaries in the front of the Strelky village, ${ }^{17}$ the presented pastures and fields for this church of the Holy Virgin Mary, which from ancient times has been considered this pond in another holding property of the Eastern Church of the city of Stara Bobrka. To the esteemed parson Matthew of Lakno, the provost of Chełm ${ }^{18}$ cathedral and the parson of the church of the Holy Virgin Mary in Bobrka, together with all law of owning and property, we are giving, releasing and granting forever and ever for the mentioned church of the Holy Virgin Mary in Bobrka the holding, having, possessing, management and provisions and benefits for this church to belong, as being better and more useful to the lord Matthew, as the parson of this church obviously, through the part, this however added, that the lord Matthew and his successors will hold. Instead, they will have to carry out one mass quarterly for our predecessors and parents - who are already dead. For this all our seal now is suspended on written testimony in the presence of nobles and titled lords, the judge Kmita ${ }^{19}$ of Halych, Nicholas de Balii et Bartholomew, and other faith worthy witnesses concerning the case at the house of residence of this lord Kmita in Bobrka on Tuesday, on the feast of glorious St. Stephen the First Martyr, the year of the Lord $1463^{20}$.

${ }^{17}$ Nowadays, Strilky is a village in Peremyshlyany district, Lviv region, Ukraine.

${ }^{18}$ Ukrainian: Хомм, Kholm.

${ }^{19}$ Literally Cmicza, it seems, is more close to the widespread Kmita.

${ }^{20}$ In Nomine domini. Amen. Ad perpetuam hujus rei memoriam, et que fiunt sub // tempore, ne simul evanescent cum tempore necessaria est ea testium annotationem // et scripti officio perhenuare. Proinde, Nos Nicolaus, Petrus, Sciborius, Andreas // et Johannes, filii olim strenua militis domini Petri Wnuczek, succamerarii leopoliensis, heredes, advocatie in Bobrca personaliter mani indivis attendenti Ecclesiam Sanctissime // Virginis Marie in Bobrca suis nostri honorari proventionem, et in majori parte deficere // et carere piscibus consuetude tamen harum Terrarum Russie tenet fere per omnia // loca, quia rectores Ecclesiarum piscinas habere consuveverunt, videntes etiam hanc vitam // presentem esse momentaneam et nisecuram volens saluti et animalibus nostris et progenitorum // nostrorum predecessorum jam vita finictorum subvenire locum paratum cum aggere in metis // et limitibus ville Strelki ex praeposito laneorum et agrorum ad eandem Ecclesiam Sanctissime // Marie Virginis ex antiquis spectantium in alia tenuent propter proprietate eiusdem piscine Ecclesia // orientalis ville Stara Bobrca, venerabili domino Mathiam de Lakno, preposito cathedralis // Ecclesie Chelmensis et Rectori Ecclesie Sanctissime Marie Virginis in Bobrca, cum omni jure, dominio et proprietate damus, liberimus et largimus perpetue et in evum ad eadem // Ecclesiam Sanctissime Virginis Marie in Bobrca tenendam, habendam, possidendam, unifruendam, // gubernandam et provisibus et utilitatibus eiusdem Ecclesie pertendis, prout melius et // utilius prefato domino Mathie, Rectori eiusdem Ecclesie videbitur pro parte hoc tamen adiuncto, // que prefatus dominus Mathias et sui succesores tenebuntur, habeantur singulis temporibus // quatour, unam misam pro predecessoribus et pro genitoribus nostris iam defunctis // celebrare. Harum omnibus sigillum nostrum presentibus est subapensum testimonio // literrarum, presentibus generosis et nobilibus dominis Cmitza 
It seems that this document concerned the liquidation of the parish of St. John the Baptist of Eastern rite of Bibrka ${ }^{21}$. The parson of it and spiritual leader of the local Ruthenian community was Gryn ${ }^{122}$. Local Christians that followed the Eastern rite would have belonged to the ecclesiastical jurisdiction of the Metropolitan of the "inferior" part of the Metropolitanate of Kyiv, Gregorios Bulgar, who was appointed by Pope Pius II.

The contents of documents of 1463 and 1469 are difficult to interpret unambiguously. Taking into account the research of Andrzej Janeczek and several Ukrainian local historians, it could be that Magdeburg law was extended to all residents of Bibrka at this time ${ }^{23}$. Therefore, King Casimir IV Jagiellon could not confirm in 1469 the seizure of feudal property in the local parish of Eastern rite of St. John the Baptist. Still, it is not known for sure for what reason the king did not confirm the transfer in 1469. In view of the extension of Magdeburg law to all residents of Bibrka, or because he was not informed about the act of 1463, perhaps he had expected that the Christians of Eastern rite of the city would follow the Church Union with the Holy See - as was the case in releasing the eparchy of Peremyszl from secular jurisdiction ${ }^{24}$.

On the other hand, King Casimir IV Jagiellon recognized the privileged position of the Catholic parish in Bibrka and the necessity to revere Catholic saints. The annual fair was to take place on the feast of St. Francis of Assisi (1181/1182-1226), who is not revered in the Eastern ecclesiastical tradition: "Furthermore, the annual fair or market day [will be at Bibrka] twice a year. The

Scabimo Haliciensis, Nicolao // de Baliy et Barthossio et aliis quampluribus fidedignis testibus circa premissa. // Actum et datum in domo hitationis eiusdem dominum Cmitza in Bobrca, feria secunda, // ipso festo sancti Stephani prothomartiris gloriosi, anno domini millesimo quadringentessimo // sexagesimo tertio. Lviv, The Central State Historical Archive in Lviv, fund 131: the Collection of charters on parchment, description 1, case No. 185: Darcha hramota syniv lvivskoho pidkomoriia Vnucheka Petra rektoru kostelu u Bibrtsi Matviiu ta yoho nastupnykam na stavok z hrebleiu u s. Strilky [The gift charter of the sons of the land surveyor of Lviv Peter Wnuchek to the parson of the church in Bibrka Matviy and his successors for the pond with the dam in the village of Strilky].

${ }^{21}$ The parish should be the center of the autonomous sentiments of local Ruthenians. In general, an autonomous administrative unit outside the community on Magdeburg law in the Crown of Poland and the Grand Duchy of Lithuania was called a "juridica".

${ }^{22}$ Ukrainian local historian, Yaropolk Tsaryk, thinks that the parson Gryn' held his position in 1445. Another point of view is that the parson occupied this position as of 1474 . Of note, the Orthodox parish of Bibrka was still functioning up to 1661, despite the decision of 1463. Ya. Tsaryk, Dukhovni sviatyni Bibrky [Spiritual shrines of Bibrka], Bibrka-Lviv 2000, pp. 7-9

${ }^{23}$ A. Janeczek, Exceptis schismaticis. Upośledzenie Rusinów w przywilejach prawa niemieckiego Władysława Jagiełły [in:] Przegląd historyczny, 1984, №3, pp. 540-541

${ }^{24}$ Akta grodzkie i ziemskie z czasów Rzeczypospolitej Polskiej z Archiwum tak zwanego bernardyńskiego we Lwowie, Lwów 1878, t. 7, No. 60 
first [will be] in the octave of the Feast of Corpus Christi and the other for the feast of St. Francis"25. Alongside, the general tendency of church-political conjuncture was that the king could not support the Orthodox, who wanted to elect Grand Duke of Lithuania - who was not from Jagiellonian dynasty ${ }^{26}$. The degree of loyalty of Ruthenians of Bibrka who followed Eastern rite to the royal power is unknown. Besides, there was no mention of privileges for the parish of St. John the Baptist in the granting of Magdeburg law to the (Catholic) community of Bibrka in 1469. Therefore, even if the property of the parish of Eastern rite was not transferred, Catholics still became the privileged community in the city.

Thus, the direct information on the early history of the Roman Catholic parish in Bibrka (Bobrka, Bóbrka) is contained in three sources. The first is the memorial board on the north wall of the church of St. Nicholas and St. Anne in Bibrka, the second is the privilege of 1463 and the third is the written records of the Crown Metrics (Metrica Regni Poloniae). Herein it states that the Holy Virgin Mary was the patron of the local Roman Catholic parish in Bibrka in the $15^{\text {th }}$ century. Furthermore, the contents of the relevant documents testify that Catholics had become the privileged community in the city.

Alongside the Roman Catholic, the parish of St. John the Baptist of Eastern rite in Bibrka functioned despite the attempt by Polish government officials to seize its property and give it over to the Catholics in 1463 . No reports of confirmation of this transfer by King Casimir IV Jagiellon in the granting of Magdeburg rights to the community of Bibrka in 1469 were found. The king, however, confirmed another privilege, the original version of which is not known today, that was presented by the parson of the Catholic parish of Bibrka, Matthew from Starolomza, and the scribe of the land of Halych. The reason why King Casimir IV Jagiellon did not confirm the transfer of 1463 then is not known for sure. Perhaps, he expected that the Christians of the city who followed the Eastern rite would follow the Church Union with the Holy See.

${ }^{25}$ Preterea forum annale seu // nundinarum bis in anno. Primum videlicet in octava Corporis Christi // et aliud pro festo Sancti Francisci. Warsaw, AGAD, zespół No. 4: MK, seria No. 1, sygnatura No. 54 , fol. $183 \mathrm{r}$

${ }^{26}$ O. Halecki, Od unii Florenckiej do unii Brzeskiej, tłum. A. Niklewicz OSU, Lublin-Rzym 1997, t. 1, p. 133 


\section{Bibliography}

\section{Sources}

- Akta grodzkie i ziemskie z czasów Rzeczypospolitej Polskiej z Archiwum tak zwanego bernardyńskiego we Lwowie, t. 7, Lwów 1878.

- Kraków, Biblioteka Jagiellońska, rkps. 33: Historiae Polonicae, tomus II.

- Kraków, Biblioteka Książąt Czartoryskich, 289 Perg.: Aleksander czyli Witold wielki książę litewski przystępuje do zawartego między Władysławem królem polskim i Zygmuntem królem rzymskim i węgierskim układu, którego treść powtarza [Alexander or Vytautas the Grand Duke of Lithuania joins the threaty between King of Poland Władysław and King of Romans and Hungary Sigismund, repeating its content].

- Lviv, the Central State Historical Archive in Lviv, fund 131: the Collection of charters on parchment, description 1, case No. 16: Hramota korolia Vladyslava II z obitsiankoiu ne viddavaty nikomu v piddanstvo $\mathrm{m}$. Lviv ta lvivski zemli, zberihshy yikh dlia sebe, svoikh ditei i Polskoho korolivstva [The chapter of King Wladyslaw II with the promise not to give anyone the ownership of Lviv and Lviv lands, keeping its for self, his children and the Kingdom of Poland].

- Lviv, The Central State Historical Archive in Lviv, the Central State Historical Archive in Lviv, fund 131: the Collection of charters on parchment, description 1, case No. 185: Darcha hramota syniv lvivskoho pidkomoriia Vnucheka Petra rektoru kostelu u Bibrtsi Matviiu ta yoho nastupnykam na stavok z hrebleiu u s.Strilky [The gift charter of the sons of the land surveyor of Lviv Peter Wnuchek to the parson of the church in Bibrka Matviy and his successors for the pond with the dam in the village of Strilky].

- Warsaw, Archiwum Główny Akt Dawnych, zespół No. 4: MK, seria No. 1, sygnatura No. 82, fol. 89v-91r

- Warsaw, AGAD, zespół No. 4: MK, seria No. 1, sygnatura No. 54, fol. 182v-183v

\section{Literature}

- Abraham. W., Jakub Strepa arcybiskup halicki: 1391-1409, Kraków 1908.

- Buchek M., Sedelnyk I., Lvivska arkhidiietseziia latynskoho obriadu. Parafii, kostely ta kaplytsi [The Lviv archidecese of the Latin rite. Parishes, churches and chapels], Lviv 2004, part 1.

- Halecki O., Od unii Florenckiej do unii Brzeskiej, tłum. A. Niklewicz OSU, t. 1, Lublin-Rzym 1997.

- Janeczek A., Exceptis schismaticis. Upośledzenie Rusinów w przywilejach prawa niemieckiego Władysława Jagiełły [in:] Przegląd historyczny, 1984, №3, pp. 527-542

- Matsiuk O., Zamky ta fortetsi Zakhidnoi Ukrainy [Castles and fortresses of the Western Ukraine], 2-d ed., Lviv 2005.

- Shakh T., Bibrka na perekhresti vikiv: chas, podii, liudy [Bibrka at the crossroads of ages: time, events, people], Lviv 2019.

- Tsaryk Ya., Dukhovni sviatyni Bibrky [Spiritual shrines of Bibrka], Bibrka-Lviv 2000.

- Tsaryk Z., Tsaryk Ya., Misto z bobrom na herbi [The city with the beaver on a coat], Bibrka-Lviv 2009. 
- Zaucha T., Kościół parafialny p. w. św. Mikołaja w Bóbrce [in:] Materiały do dziejów sztuki sakralnej na ziemiach Wschodnich dawnej Rzeczypospolitej, J. Ostrowski (ed.), cz. 1. t. 11: Kościoły i klasztory Rzymskokatolickiego dawnego województwa Ruskiego, Kraków 2003, pp. 21-36.

Summary: The main aim of this paper is to analyze the first written records on the history of the Roman Catholic parish in Bibrka. In accomplishing this, the author has explored a memorial tablet, the content of a recently found document and the appropriate written records of the Crown Metrics. As a result, the earliest known documented evidence of donations to the local parish of the Holy Virgin Mary dates back to the reign of King of Poland Casimir IV Jagiellon.

Keywords: the Roman Catholic parish of the Holy Virgin Mary in Bibrka (Bobrka), the royal domain of Jagiellonians, donation

\section{Wczesna historia parafii rzymskokatolickiej w Bóbrce}

Strzeszczenie Głównym celem artykułu jest analiza pierwszych zapisów dotyczących historii rzymskokatolickiej parafii w Bóbrce. Aby to osiągnąć, autor zapoznał się z tablicą pamiątkową, treścią niedawno znalezionego dokumentu dotyczącego historii parafii oraz odpowiednimi zapisami Metryki Koronnej. Wyjawiono, że najwcześniejsze znane udokumentowane dowody darowizn na rzecz miejscowej parafii Najświętszej Maryi Panny pochodzą z czasu panowania króla Kazimierza IV Jagiellończyka.

Słowa kluczowe: parafia rzymskokatolicka Najświętszej Maryi Panny w Bóbrce, domena królewska Jagiellonów, darowizna 